\title{
Effect of Phosphorus Fertilizer for Maize Production in Gimbo Woreda at Kafa Zone Southern Ethiopia
}

\author{
Zelalem Addis ${ }^{1} \quad$ Shiferaw Boke ${ }^{2 *}$ \\ South Agricultural Research Institute Bonga Agricultural Research Center, P.O.Box101, Bonga
}

\begin{abstract}
The current use of commercial fertilizers in Ethiopia is not in harmony with the economics. Although, there have been nitrogen and phosphorus fertilizer rates for the production of maize, sometimes this recommendation does not work outside the experiment sites largely due to the variation of the soil fertility levels on farmer's field. Therefore, site specific fertilizer recommendation and continual updating and re-evaluation of this recommendation are a vital step for optimizing the maize grain yield. Although field experiment results are more reliable, soil test calibration research could alleviate this problem with much more benefit to farmers and the environment the average national yield. The objective of this study was to assess and evaluate phosphorus fertilizer requirement for Maize. Seven levels of $\mathrm{P}(0,10,20,30,40,50$, and 60$)$ combined with sufficient amount of $\mathrm{N} 46 \mathrm{~kg}$ and laid down in RCBD with two replication. The experiment was conducted for two consecutive years at Kaffa Zone Gimbo Wereda.TSP was used as a source of P and Urea was used as a source a common combined $\mathrm{N}$. All dose of $\mathrm{P}$ was applied at planting while $\mathrm{N}$ was applied as splitting half at planting and half after 45 days of planting crop data such as plant highest, stand count at emergency, stand count at harvest,biomass,grainyield,cobelength and 1000seedweight was collected and analyzed using SAS computer software . Composite surface soil samples $(0-20 \mathrm{~cm})$ were collected before planting, at harvest from each treatment. The highest maize production of grain yield was obtained from $30 \mathrm{~kg} \mathrm{P}^{-1} \mathrm{and}^{-1} 50 \mathrm{~kg} \mathrm{P}^{-1}$ on two $2005 / 6$ and 2006/7 consecutive years respectively. So that these levels are better for maize production .but for economic value $30 \mathrm{kgPha}^{-11}$ should be recommended for better maize production approach.
\end{abstract}

Keywords: $P$ fertilizers, Maize production

DOI: $10.7176 / \mathrm{FSQM} / 85-05$

Publication date:March $31^{\text {st }} 2019$

\section{INTRODUCTION}

Maize (Zea mays L.) is an important cereal crop which ranks the third after wheat and rice in the world (David and Adams, 1985. Crops of drier regions of the tropics). Maize is grown widely in many countries of the world. In Pakistan, maize is cultivated on an area of 880.8 thousand hectares giving annual production of 128.3 thousand tones with average yield of $1445 \mathrm{~kg} \mathrm{ha}^{-1}$ (Anonymous, 1996). The major yield producers are the United States, Brazil, France, India and Italy. In Africa, the bulk of maize produced is used as human food although it is increasingly been utilized for livestock feed. According to FAO data the area planted of maize in West and Central Africa alone increased from 3.2 million in 1961 to 8.9 million in 2001(Buresh, R.J., P.A. Sanchez and F. Calhoun, 1997).

This phenomenal expansion of the land area devote to maize resulted in increased the production from 2.4 million metric tons in 1961 to 10.6 million metric In spite of the increase in land areas under maize production, yield is still low. Some of the major causes of low maize yield are declining soil fertility and insufficient use of fertilizers resulting in severe nutrient depletion of soils. Maize requires adequate supply of nutrients particularly nitrogen, phosphorus. It is also an exhaustive crop having higher potential than other cereals and absorbs large quantity of nutrients from the soil during different growth stages. Among the essential nutrients, phosphorus is one of the most important nutrients for higher yield in larger quantity (Chen et al. 1994) and controls mainly there productive growth of plant (Wojnowska et al. 1995).

It is the second most crop-limiting nutrient in most soils. Numerous field experiments have been conducted at wide range of sites in Ethiopia involving phosphorus $(\mathrm{P})$ and Nitrogen $(\mathrm{N})$ fertilization of various crops. However, it is not site specific recommendation on phosphorus especially on the study area. Because of this it is essential initiating this topic on the study area in order to recommend appropriate rate of $\mathrm{P}$ for production of maize by increasing productivity.

\section{MATERIAL AND METHOD}

\subsection{Description of the Study Area}

The study was conducted on different 12 farmers filed for two years (2013-2015) Shomba Kichib peasant association', Gimbo district which was located at, Kaffa zone, Southern Nations Nationalities and People's Region (SNNPR). It is found within the southwestern plateau of Ethiopia and $450 \mathrm{~km}$ and $725 \mathrm{~km}$ far from Addis Ababa and Hawassa respectively. The area lies within $07^{\circ} 00^{\prime}-7^{\circ} 25^{\prime} \mathrm{N}$ Latitude and $35^{\circ} 55^{\prime}-36^{\circ} 37^{\prime} \mathrm{E}$ Longitude. The altitude of the study area ranges from 1600 to 1800 m.a.s.l. The topography is characterized by slopping and 
rugged areas with very little plain land (Matheos, 2001). It has one and long rainy season extending from March /April to October. The mean annual rainfall ranges from $1710 \mathrm{~mm}$ to $1892 \mathrm{~mm}$. Over $85 \%$ of the total annual rainfall, with mean monthly values in the range of $125-250 \mathrm{~mm}$ occurs in the 8 months long rainy season. The mean temperature ranges from $18.1^{\circ} \mathrm{C}$ to $19.4^{\circ} \mathrm{C}$ (Matheos, 2001).According to the study conducted by Bonga Agricultural Research center, out of the interviewed farmers $60 \%$ responded that they start land preparation for maize after $15^{\text {th }}$ January while $40 \%$ said that they start first tillage at the start of February indicating that Jan-Feb is accepted season for starting of tillage for maize. Millet, maize and pepper contributed to $90 \%$ of the farmers' income while $8 \%$ from livestock and $2 \%$ from off farm income.

\subsection{Treatment Set up and Experimental Design}

Seven levels of phosphorus $\left(0,10,20,30,40,50\right.$ and $\left.60 \mathrm{~kg} \mathrm{P} \mathrm{ha}^{-1}\right)$ and an absolute control were used as a treatment.RCBD design was used and the treatments were replicated two times. A spacing of $1.5 \mathrm{~m}$ and $1 \mathrm{~m}$ between blocks and between plots, $75 \mathrm{~cm}$ between rows and $30 \mathrm{~cm}$ between plants was used. Pioner variety was used as a test crop. P was applied at planting period of time while nitrogen was applied in split two times at planting and after 21 days of sowing the testing crop in all treated plots except in control. Agronomic data were recorded and analyzed through SAS Software version 9.0 .

\subsection{Crop data}

All most all the agronomic stand count at emergency, stand count at harvest,1000 seed weight, grain yield , biomass cob length and plant height were recorded on the experimentation period of time through quantitative measurement. Stand count at emergency and harvest done by counting the plants in each experimental unit during at emergency and harvest. Plant height and cob length measured through measuring tape at $90 \%$ maturity period of time. Similarly biomass, 1000 seed weight and grain yield also recorded at harvesting period of time by measuring of standardized balance

\section{RESULT AND DISCUSSION}

\subsection{Grain Yield}

The second year result of Grain yield was significantly affected by different levels of Phosphorus. Mean values of the data showed that maximum grain yield $\left(7589.9 \mathrm{~kg} \mathrm{ha}^{-1}\right)$ was produced by the treatments of $50 \mathrm{~kg} \mathrm{P} \mathrm{ha}^{-1}$, followed by $30 \mathrm{~kg} \mathrm{P} \mathrm{ha}^{-1}$ (7413.6 $\left.\mathrm{kg} \mathrm{ha}^{-1}\right)$. The control plots resulted in minimum grain yield $\left(6404.3 \mathrm{~kg} \mathrm{ha}^{-}\right.$ $\left.{ }^{1}\right)$.Phosphorus application at the rate of $50 \mathrm{~kg} \mathrm{P} \mathrm{ha}^{-1}$ resulted in long stature plants, which resulted in greater grain yield as compared to other $\mathrm{P}$ levels. This disclosed that $\mathrm{P}$ at the rate of $50 \mathrm{~kg} \mathrm{ha}^{-1}$ might be the optimum rate to cause a desirable increase in production per unit area with per unit increase in $\mathrm{P}$ content because the grain yield in the control plots was the lowest where as it was highest in the plots with $\mathrm{P}$ applied at $50 \mathrm{~kg} \mathrm{ha}^{-1}$. Increasing P above $50 \mathrm{~kg} \mathrm{ha}^{-1}$ might be excessive that had decreased the grain yield of maize which indicated that applying $\mathrm{P}$ in maize above $50 \mathrm{~kg} \mathrm{ha}^{-1}$ is might be uneconomical and just wastage of money. The increase in grain yield due to NP application was also reported by Khan et al. (1999), Maqsood et al. (2001) and Sharma and Sharma (1996).Arain et al. (1989) reported that grain yield of maize increased with increase in P application. Similar results were also reported by Hussain et al. (2006) who found that grain yield increased with phosphorus application and plots receiving $90 \mathrm{~kg} \mathrm{P} \mathrm{ha}^{-1}$ gave maximum grain yield as compared to lower dose grain yield. A good and optimum supply of $\mathrm{P}$ is associated with increased root growth due to which the plants explore more soil nutrients and moisture. That is why the grain yield was the lowest in the control plots because lack of $\mathrm{P}$ deteriorated the roots growth of the plants which negatively affected the other physiological functions of the maize plants in the control plots.

\subsection{Stand Count at Emergency and Harvest}

The result of stand count and emergency analysis were depicted in table 1. Application of different levels of phosphorus fertilizer was significantly affected stand count at emergency and at harvest. The highest stand count at emergency and harvest result was recorded on the level of $50 \mathrm{~kg} \mathrm{P} \mathrm{ha}{ }^{-1} 75.833$ and70.792 whereas as the positive control plots on the second year result at $(\mathrm{p}<0.005)$ lowest as compare to others $($ table 1$)$.This indicated that $\mathrm{p}$ is readily translocate within the plants, moving from older to younger tissues as the plant forms cells and develops roots, stems and leaves (Ali et al. 2002). This improves Adequate P results in rapid growth and earlier maturity and improves the quality of vegetative growth. Phosphorus deficiency is responsible for crooked and missing rows as kernel twist and produce small ears nubbies in maize. Its deficiency is widespread in $90 \%$ of the Pakistani soils and the application of phosphatic fertilizers is considered essential for crop production and its deficiency will slow overall plant growth and stand (Rashid and Memon, 2001). This phenomenon is very common in most Ethiopian Soils including south west regions. 
Table 1. phosphorus application effect on mean stand count at emergency, stand count at harvest, cob length, plant height, grain yield,biomas and 1000 seed weight of year1 and 2 respectively

\begin{tabular}{|c|c|c|c|c|c|c|c|c|c|c|c|c|c|c|}
\hline & Year & $(2013$ & & & & & & & & & $\operatorname{ar} 2($ & 14/15) & & \\
\hline $\mathbf{T r}$ & $\overline{\mathrm{SCE}}$ & $\mathrm{SCH}$ & $\begin{array}{l}\mathrm{CL} \\
(\mathrm{cm})\end{array}$ & $\begin{array}{l}\mathrm{PH} \\
(\mathrm{m})\end{array}$ & $\begin{array}{c}\mathrm{GY} \\
\left(\underset{1}{\mathrm{~kg}} \mathrm{ha}^{-}\right.\end{array}$ & $\begin{array}{c}\mathrm{BM} \\
\left(\begin{array}{c}\mathrm{kg} h \mathrm{~h}^{-} \\
1\end{array}\right)\end{array}$ & TSW/g & $\overline{\mathrm{SCE}}$ & $\mathrm{SCH}$ & $\begin{array}{l}\mathrm{CL} \\
(\mathrm{cm})\end{array}$ & $\begin{array}{l}\mathrm{PH} \\
(\mathrm{m})\end{array}$ & $\begin{array}{c}\text { GY } \\
\left(\mathrm{kg} \mathrm{ha}^{-1}\right)\end{array}$ & $\begin{array}{c}\mathrm{BM} \\
\left(\mathrm{kg} \mathrm{ha}^{-}\right. \\
1\end{array}$ & $\overline{\mathrm{TSW} / \mathrm{g}}$ \\
\hline $\mathbf{0 , 0}$ & & & & & & & & $70.6^{\mathrm{bcd}}$ & $63.9^{\mathrm{bc}}$ & 23.2 & 2.4 & $6404.3^{\mathrm{b}}$ & 25530 & 409.6 \\
\hline 46,0 & 69.6 & 56.8 & 26.3 & 2.4 & 4856.7 & 31837 & 409.6 & $67.2^{\mathrm{d}}$ & $61.8^{c}$ & 23.1 & 2.4 & $6629.0^{\mathrm{b}}$ & 26091 & 407.6 \\
\hline 46,10 & 70.5 & 57.3 & 25.6 & 2.3 & 4913.3 & 31800 & 413.4 & $69.0^{\mathrm{cd}}$ & $65.4^{\mathrm{bc}}$ & 22.9 & 2.4 & $7249.4^{\mathrm{a}}$ & 28009 & 414.0 \\
\hline 46,20 & 67.0 & 55.1 & 26.2 & 2.3 & 5041.7 & 30754 & 405.8 & $73.7^{\mathrm{ab}}$ & $67.2^{\mathrm{ab}}$ & 23.6 & 2.4 & $7194.2^{\mathrm{a}}$ & 28033 & 414.6 \\
\hline 46,30 & 70.6 & 61.0 & 25.5 & 2.2 & 5200.0 & 35233 & 412.4 & $73.5^{\mathrm{ab}}$ & $68.2^{\mathrm{ab}}$ & 22.5 & 2.5 & $7413.6^{\mathrm{a}}$ & 27914 & 401.0 \\
\hline 46,40 & 70.6 & 59.9 & 26.0 & 2.3 & 4815.0 & 35760 & 413.3 & $72.7^{\mathrm{abc}}$ & $68.2^{\mathrm{ab}}$ & 23.4 & 2.5 & $7272.4^{\mathrm{a}}$ & 28640 & 411.0 \\
\hline 46,50 & 67.8 & 60.1 & 25.8 & 2.3 & 5033.3 & 33488 & 409.3 & $75.8^{\mathrm{a}}$ & $70.8^{\mathrm{a}}$ & 23.3 & 2.5 & $7589.9^{\mathrm{a}}$ & 27358 & 405.8 \\
\hline 46,60 & 68.3 & 55.9 & 28.1 & 2.3 & 4710.0 & 31320 & 400.3 & $71.1^{\mathrm{bcd}}$ & $66.5^{\mathrm{ab}}$ & 23.4 & 2.5 & $7145.9^{\mathrm{a}}$ & 27823 & 403.7 \\
\hline LSD & NS & NS & NS & NS & NS & NS & NS & 4.5 & 4.6 & NS & NS & 494.9 & NS & NS \\
\hline CV & 20 & 18 & 17 & 8 & 19 & 21 & 5 & 11 & 12 & 9 & 5 & 12 & 16 & 9 \\
\hline
\end{tabular}

\section{CONCLUSIONS AND RECOMMENDATION}

This study further confirms the role of phosphorus fertilizer in increasing growth and grain yield in maize production. From the result of the experiment, application rate of $46 \mathrm{kgN} / \mathrm{ha}+50 \mathrm{kgP} / \mathrm{ha}$ may be recommended for increasing maize yield particularly in the study area (table1) on second year. However, application of $46 \mathrm{kgN} / \mathrm{ha}+30 \mathrm{kgP} / \mathrm{ha}$ can also bring about increase in the yield of maize on first year. This will greatly benefit and recommend to farmers in area where supply of phosphorus fertilizer is low or in cases where farmers cannot afford the cost of high fertilizer input. Beside this stand count at emergency and at harvest also confirmed the grain yield at levels 30 and $50 \mathrm{~kg} \mathrm{p} \mathrm{ha-}{ }^{1}$ on first year and second year respectively. In general further research study with calibration of $\mathrm{P}$ should be done in order to get appropriate site specific recommendation on the study area.

\section{REFERENCE}

Ali, J., J. Bakht, M. Shafi, S. Khan and W.A. Shah. 2002. Uptake of nitrogen as affected by various combinations of nitrogen and phosphorus. Asian J. Pl. Sci. 1: 367-369.

Anonymous, 1996. Economic Survey, Government of Pakistan Division economic Advisor's Wing, Islamabad, pp: 17.

Arain, A.S., S.M. Aslam and A.K.G. Tunio. 1989. Performance of maize hybrids under varying NP fertilizer environments. Sarhad J. Agric. 5(6): 623-626.

Buresh, R.J., P.A. Sanchez and F. Calhoun, 1997. Replenishing soil fertility in Africa. SSSA Spec. Publ. 51. SSSA and ASA, Madison, WI.

Chen, M.L., X.L. Jiang, B.Y. Zoov and Z.Y. Zheri. 1994. Mathematical models and best combination of high yield cultivation technique for rapeseed variety Zhenyouyoum. Acta Agric Zhejiiangenesis. 6:22-26.

Hussain, N., A.Z. Khan, H. Akbar and S. Akhtar. 2006. Growth factors and yield of maize as influenced by phosphorus and potash fertilization. Sarhad J. Agric. 22(4): 579-583.

Khan, M.A., M.U.Khan, K.Ahmad and M.Sadiq.1999.Yield of maize hybrid-3335 as affected by NP levels.Pak.J.Biol.sci.2:857-859.

Maqsood, M., A.M. Abid, A. Iqbal and M.I. Hussain. 2001. Effect of various rates of nitrogen and phosphorus on growth and yield of maize. Pak. J. Biol. Sci. 1: 19-20.

Matheos E (2001). Inventory of species in Bonga Forest .Institute of Biodiversity Conservation and Research Technical Report No.1. Addis Ababa.

Rashid, A. and K.S. Memon. 2001. Soil and fertilizer phosphorus. Soil Sci. B. Elenaand R. Bantel (Eds). National Book Foundation, Islamabad, Pakistan. pp. 300-302.

Sharma, J.P. and U.C. Sharma. 1991. Effect of nitrogen and phosphorus on the yield and severity of turcicum blight in maize Nagaland. Indian Phytopath. 44: 383-385.

Wojnowska, T., H. Panak and S. Seikiewiez. 1995. Reaction of winter oilseed rape to increasing levels of nitrogen fertilizer application under condition of Ketizyn Chernozem. Rosling Oleiste. 16:173-180. 